\title{
Impact of cluster frontline demonstration programme on the yield of chickpea (Cicer arietinum 1.) in Mehsana district of Gujarat, India
}

\author{
Patel B. K. ${ }^{1}$ and Patel R. A. ${ }^{2}$
}

${ }^{1}$ Subject Matter Specialist (Crop Production), Krishi Vigyan Kendra, Ganpat University, Mehsana, Gujarat, India

${ }^{2}$ Senior Scientist and Head, Krishi Vigyan Kendra, Ganpat University, Mehsana, Gujarat, India

\begin{abstract}
Cluster Front Line demonstrations (CFLDs) is a unique approach to provide an direct interface between researcher and farmers as the scientists are directly involved in planning, execution and monitoring of the demonstrations. The present study was conducted to assess the impact of cluster frontline demonstrations of chickpea crop in the Mehsana district of Gujarat state. Chickpea (Cicer arietinum L.) is a highly nutritious grain legume crop and is widely appreciated as health food as well as high return crop. Cluster Front line demonstrations were conducted at 93 farmers' fields under 37.2 ha, to demonstrate production potential and economic benefits of improved technologies. Study revealed that improved cultivation practices comprised under CFLDs viz., improved varieties, proper tillage, proper seed rate, line sowing using seed cum fertilizer drill, seed treatment with chemical fungicide, dual inoculation of Rhizobium + PSB, RDF as per STV, water management at critical stages, weed management and application of IPM module for the management of insect (Specially on gram pod borer) resulted in increase in yield in gram crop over the check plots. The improved technologies gave higher yields and recorded a mean yield of 20.60 and 21.45 q/ha chickpea yield during 2017-18 and 2018-19, respectively which was 22.26 and 16.39 percent higher compared to prevailing farmers practice. The benefit: cost ratios of chick pea cultivation under improved practices were 4.10 and 3.82 as compared to 3.20 and 3.43 under farmer practices for the two consecutive years.
\end{abstract}

Keywords-Chickpea, Economics, GJG-3, Yield, technology gap, extension gap, technology index, CFLDs.

\section{INTRODUCTION}

Chickpea (Cicer arietinum L.) is the premier pulse crop widely consumed in India. It is an important rabi season food legume having extensive geographical distribution and contributing 39 percent to the total production of pulse in the country (Singh et al., 2013). It is the cheapest source of protein and is the inseparable part of the daily diets of every Indians. It also plays an important role in sustainable agriculture enriching the soil through biological nitrogen fixation (BNF). It is a good source of protein $(18-22 \%)$, carbohydrate $(52-70 \%)$, fat (4$10 \%$ ), minerals (calcium, phosphorus, iron) and vitamins (Singh et al., 2014). It is an excellent animal feed. Its straw also had good forage value. Chickpea is grown in more than 50 countries $(89.7 \%$ area in Asia, $4.3 \%$ in Africa, $2.6 \%$ in Oceania, $2.9 \%$ in Americas and $0.4 \%$ in Europe). In India, the area under chickpea was 8.39 million hectares with a production of 7.81 million tons and productivity of 931kg/ha during rabi-2016-17 (FAOSTAT, 2017). The major chickpea producing states are Madhya Pradesh, Uttar Pradesh, Rajasthan, Maharastra, Andhra Pradesh, Gujarat, Karnataka, Haryana, Bihar and West Bengal. In Gujarat, area under chickpea was 0.295 million hectares with a total production of 0.364 million tones and productivity of $1235 \mathrm{~kg} / \mathrm{ha}$ during 2017-18 (Anon., 2017). Mehsana district of Gujarat occupies 597 hectares of land and 7670 qt. production with average productivity of 1285 $\mathrm{kg} / \mathrm{ha}$ of chickpea(Anon., 2017). Its productivity is far below the potential yield. Abiotic stresses are responsible 
for declining of yield potential (Singh et al., 2013). For making the nation self- sufficient in pulses, the productivity levels need to be increased substantially from $598 \mathrm{~kg}$ per ha to $1,200 \mathrm{~kg}$ per ha by 2020 (Ali and Kumar, 2005).Through much progress has been made in the field of agriculture research and education, but benefits of these developments could not be realized by the farming community because of low adoption of technologies at the farmers level. Cluster Front line demonstration (CFLDs) is introduced by the Indian Council of Agricultural Research, New Delhi with inception of technology mission of pulse and oil seed crops during mid eighties. The field demonstration took place under the close supervision of scientist of the KVKs.

Through survey, farm diagnostic visit and farmers meeting it was realized that the reason behind the lower productivity was due to lack of improved variety, no seed treatment, imbalance use of inorganic fertilizers, lack of knowledge about IPM practices etc. Among the biotic stress, the gram pod borer is a major pest occurring for 75 per cent pod damage in the crop (Krishan Kant et al., 2007).To combat the causes of yield reduction and technology gap, dissemination of recommended technologies of chickpea through cluster frontline demonstration were organized at farmer's field during 2017 -18 and 2018-19.

\section{MATERIALS AND METHODS}

Krishi Vigyan Kendra, Mehsana of Gujarat state conducted cluster frontline demonstrations on chickpea at farmers' field to assess its performance during Rabi seasons of the year 2017-18 and 2018-19 in different villages of Mehsana district. During these two years, 37.2 hectares with 93 number of demonstration under chickpea were laid out with improved management practices using improved variety GJG-3. In general, the soil of the area under study was sandy loam with low to medium fertility status. Each demonstration was of 0.4 ha area and the components of demonstration comprised of improved varieties, proper tillage, proper seed rate, line sowing using seed cum fertilizer drill, seed treatment with chemical fungicide, dual inoculation of Rhizobium + PSB, RDF as per STV, water management at critical stages, weed management and application of IPM module for the management of gram pod borer and other pests. In the demonstration one control plot was also kept in which the farmers practices were carried out. The sowing was done during Mid November under irrigated conditions and harvested during last fortnight of March. The difference between demonstration package and existing farmers practice are given in Table 1. Full gap was observed in case of use of HYVs, seed treatment, use of micronutrient and pest management and partial gap was observed in fertilizer dose, irrigation and weed management, which definitely was the reason of not achieving potential yield. Farmers were not aware about recommended technologies. Farmers in general used local or old-age varieties instead of the recommended high yielding resistant varieties. Unavailability of seed in time and lack of awareness were the main reasons. Farmers applied higher seed rate than the recommended.

Table 1: Gap analysis between recommended practices and farmer's practices in chickpea.

\begin{tabular}{|l|l|l|l|}
\hline Technology & Improved practices & Farmers practice & Gap (\%) \\
\hline Use of HYVs & GJG - 3 & Local & Full gap \\
\hline Land preparation & Ploughing and harrowing & Ploughing and harrowing & Nil \\
\hline Seed rate & $60 \mathrm{~kg} / \mathrm{ha}$ & Line sowing & High seed rate \\
\hline Sowing method & Line sowing & No seed treatment & No gap \\
\hline $\begin{array}{l}\text { Seed treatment } \\
\text { Fertilizer dose } \\
\text { (NPK kg/ha) }\end{array}$ & Bio fertilizers and Trichoderma & Use only DAP & Full gap \\
\hline $\begin{array}{l}\text { Macronutrient } \\
\text { Weed } \\
\text { management }\end{array}$ & $\begin{array}{l}\text { Sulphur 20 kg/ha } \\
\text { and 55 DAS }\end{array}$ & Po Macronutrient & Full gap \\
\hline $\begin{array}{l}\text { Irrigation } \\
\text { One at branching, flowering, pod }\end{array}$ & Partial gap \\
\hline
\end{tabular}




\begin{tabular}{|l|l|l|l|}
\hline & development stage and grain filling stage & & \\
\hline Pest & HNPV $-450 \mathrm{LE}$, Pheromone trap - 10 nos, & Indiscriminate application of \\
Management & Neem oil (10000ppm) - 1.8 lit and Beauveria & Mix/different pesticide to \\
control pest & Full gap & \\
(pod borer) & & & \\
\hline
\end{tabular}

Before conducting the demonstration, Krishi Vigyan Kendra is conducted training to the selected farmers on sowing and nutrient management, pest management and post harvest management aspect. The demonstrations on farmers' fields were regularly monitored by scientists of Krishi Vigyan Kendra, Mehsana right from sowing to harvesting. The yield data were collected from both the demonstration and farmers practice using random crop cutting method and analysed by using simple statistical tools. Selection of site and farmers' selection were considered as suggested by Choudhary(1999). The observation on grain yield (qtl/ha) and straw yield (qtl/ha) were recorded. Other parameters like increasing in yield $(\%)$, technology gap $(\%)$,extension $\operatorname{gap}(\%)$ and technology index were worked out as suggested by Kadian et al.,(1997).The gross return, net return, cost of cultivation and benefit cost ration were also calculated. The data output were collected from both RP as well as farmers practices and finally the extension gap, technology gap, technology index along with benefit cost ratio were workout (Samui et al.,2000) as given below:

Increasing yield $(\%)=$ Demonstration Yield - Farmers Yield X 100 / Farmers Yield

Technology gap $=$ Potential Yield - Demonstration yield

Extension gap $=$ Demonstration Yield - Farmers yield

Technology index $=$ Potential Yield - Demonstration Yield X 100 / Potential Yield

\section{RESULTS AND DISCUSSION}

Yield

Cluster Frontline demonstrations (CFLD) are effective tools in introducing various new technologies to the farmers and educational them and to increase the farmer's knowledge and confidence level by comparison of productivity levels between improved production technologies in demonstration trials. The data (Table 2) indicated that the cluster front line demonstration has given a good impact over the farming community of Mehsana district as they were motivated by the new agricultural technologies applied in the demonstrations. Results of 93 frontline demonstrations indicated that the cultivation practices comprised under CFLD viz., use of improved variety (GJG-3), balanced application of fertilizers@ 20:40:0:20 kg NPKS per ha, line sowing, timely weed management, water management at critical stages and control chickpea pod borer through IPM module, produced on an average 20.60 and $21.45 \mathrm{q} / \mathrm{ha}$ chickpea yield during 2017-18 and 2018-19, respectively which was 22.26 and 16.39 percent higher compared to prevailing farmers practice (Table 2). The results indicated that the cluster front line demonstrations have given a good impact over the farming community of Mehsana district as they were motivated by the new agricultural technologies applied in the CFLD plots (Table 1). This finding is in corroboration with the findings of Poonia and Pithia (2011) and Raj et al. (2013).The data presented in Table 2 indicated that the average yield of chickpea under package demonstration was $21.03 \mathrm{q} / \mathrm{ha}$ whereas that the yield under farmers practice was $17.64 \mathrm{q} / \mathrm{ha}$. This indicated that use of improved technology for chickpea production contributed 19.33 per cent higher production than the local practice. The above findings were also similar to the findings of Singh (2002), Poonia and Pithia (2011), Patel et al.,(2013) and Raj et al.,(2013). 
Table 2 : Productivity,Technology gap, Extension gap and Technology Index of Chickpea as grown under CFLD and existing package of practices

\begin{tabular}{|c|c|c|c|c|c|c|c|c|c|c|}
\hline \multirow{2}{*}{ Year } & \multirow{2}{*}{ Variety } & \multirow{2}{*}{$\begin{array}{c}\text { Area } \\
\text { (ha) }\end{array}$} & $\begin{array}{c}\text { No. of } \\
\text { Demo }\end{array}$ & \multicolumn{2}{|c|}{ Grain Yield (q/ha) } & \multicolumn{2}{c|}{$\begin{array}{c}\text { Technology } \\
\text { Gap } \\
\text { increase }\end{array}$} & $\begin{array}{c}\text { Extension } \\
\text { Gap } \\
(\mathbf{q} / \mathbf{h a})\end{array}$ & $\begin{array}{c}\text { Technology } \\
\text { Index } \\
(\mathbf{q} / \mathbf{h a})\end{array}$ \\
\hline $\begin{array}{c}2017- \\
18\end{array}$ & GJG-3 & 7.20 & 18 & 26.25 & 20.60 & 16.85 & 22.26 & 5.65 & 3.75 & 21.52 \\
\hline $\begin{array}{c}2018- \\
19\end{array}$ & GJG-3 & 30.0 & 75 & 26.25 & 21.45 & 18.43 & 16.39 & 4.80 & 3.02 & 18.29 \\
\hline Average & - & - & - & $\mathbf{2 6 . 2 5}$ & $\mathbf{2 1 . 0 3}$ & $\mathbf{1 7 . 6 4}$ & $\mathbf{1 9 . 3 3}$ & $\mathbf{5 . 2 3}$ & $\mathbf{3 . 3 9}$ & $\mathbf{1 9 . 9 1}$ \\
\hline Total & - & $\mathbf{3 7 . 2 0}$ & $\mathbf{9 3}$ & - & - & - & - & - & - & - \\
\hline
\end{tabular}

\section{Technology gap}

The technology gap in the demonstration ranged from 4.80 to $5.65 \mathrm{q} / \mathrm{ha}$ yields over potential yield. and average technological gap during the period of study is $5.23 \mathrm{q} / \mathrm{ha}$. (Table 2). The technology gap observed may be attributed to the dissimilarity in soil fertility, salinity and erratic rainfall and other vagaries of weather conditions in the area. Hence, variety wise location specific recommendation appears to be necessary to minimize the technology gap for yield level in different situations and similar finding were found by Mukherjee (2003) and Mitra and Samajdar(2010).

\section{Extension gap}

The yield gaps presently ranging between 3.02 to 3.75 $\mathrm{q} / \mathrm{ha}$. The average extension gap during the period of study was $3.39 \mathrm{q} / \mathrm{ha}$ (Table 2). This emphasized the need to educate the farmers through various means for the adoption of improved agricultural production technologies to reverse this trend of wide extension gap. More and more use of latest production technologies with high yielding variety will subsequently change this alarming trend of galloping extension gap. The new technologies will eventually lead to the farmers to discontinue the old technology and to adopt new technology (Table 1). This finding is in corroboration with the findings of Hiremath and Nagaraju (2010).

\section{Technology Index}

The technology index shows the feasibility of the evolved technology at the farmer's fields and the lower the value of technology index more is the feasibility of the technology (Jeengar et al. 2006). As such, fluctuation in the technology index was ranged from $18.29 \%$ in 2018 19 to $21.52 \%$ in 2017-18 and average technology index during the period of study is $19.91 \%$ (Table2) These findings corroborate with the findings of Mokidue et al., (2011) and Tomar (2010).

\section{Economic}

The input and output prices of commodities prevailed during each year of demonstration were taken for calculating cost of cultivation, gross return, net return and benefit cost ratio (Table 3). The net return from recommended practices was Rs. 66023 to Rs. 76994 while the net return from farmer practices was Rs. 48951 to Rs. 63199.It means that net return from demonstration was higher than the farmer practices. The average additional cost during the period of study was Rs.137 per ha and additional net return was Rs.15434 per ha. The increase benefit: cost ratio was also calculated. The benefit cost ratios of under recommended practices were higher (4.10 and 3.82) as compared to farmers practice (3.20 and 3.43). This may be due to higher yield obtained under recommended practices compared to farmer's practices. Thus, it was clearly showed that the demonstration of chickpea with full package was better than farmer's practices. Similar result has been reported by earlier by Teggelli et al.(2015), Tomar; (2010) and Mokidue et al ;(2011), Prajapati et al.(2019), Upesh Kumar et al.(2019) 
Table 3: Economics evaluation of demonstrated package of practices

\begin{tabular}{|c|c|c|c|c|c|c|c|c|c|c|c|c|}
\hline \multirow[t]{2}{*}{ Year } & \multicolumn{2}{|c|}{$\begin{array}{ll}\text { Grain } & \text { Yield } \\
(\mathrm{q} / \mathrm{ha}) & \end{array}$} & \multicolumn{2}{|c|}{$\begin{array}{l}\text { Biological } \\
\text { Yield(/ha) }\end{array}$} & \multicolumn{2}{|c|}{$\begin{array}{l}\text { Gross } \\
\text { Expenditure } \\
\text { (Rs/ha) }\end{array}$} & \multicolumn{2}{|c|}{$\begin{array}{ll}\text { Gross } & \text { Return } \\
\text { (Rs/ha) } & \end{array}$} & \multicolumn{2}{|c|}{$\begin{array}{l}\text { Net Returns } \\
\text { (Rs/ha }\end{array}$} & \multicolumn{2}{|c|}{ B:C Ratio } \\
\hline & Demo & Local & Demo & Local & Demo & Local & Demo & Local & Demo & \begin{tabular}{|l} 
Local \\
\end{tabular} & Demo & Local \\
\hline $\begin{array}{ll}2017 & - \\
18 & \end{array}$ & 20.60 & 16.85 & 19.70 & 15.25 & 21302 & 22262 & 87325 & 71213 & 66023 & 48951 & 4.10 & 3.20 \\
\hline $\begin{array}{ll}2018 \quad- \\
19\end{array}$ & 21.45 & 18.43 & 20.75 & 16.45 & 27292 & 26060 & 104287 & 89259 & 76994 & 63199 & 3.82 & 3.43 \\
\hline Average & 21.03 & 17.64 & 20.23 & 15.85 & 24297 & 24161 & 95806 & 80236 & 71509 & 56075 & 3.96 & 3.32 \\
\hline
\end{tabular}

\section{CONCLUSION}

The productivity enhancement under cluster front line demonstration over traditional method of rabi chickpea cultivation created greater awareness and motivated the other farmers to adopted appropriate production technology of chickpea in district. The selection of specific technology like use of improved variety (GJG-3), balanced application of fertilizers

$(\mathrm{N}: \mathrm{P}: \mathrm{K}: \mathrm{S}$ @ 20:40:0:20 kg NPKS per ha), line sowing, timely weed management, water management at critical stages and control chickpea Pod borer through IPM module were undertaken in a proper way. Cluster Frontline demonstration was effective in changing attitude of farmers towards pulse cultivation. Cultivation of demonstrated plots of rabi chickpea with improved technologies has increased the skill and knowledge of the farmers. Cluster Front line demonstration also helped in replacement of local varieties with improved recommended varieties. This also improved the relationship between farmers and scientist and built confidence between them. These technology maybe popularize through enhancing awareness among the farming community by regular campaigning of the technology, conduct large scale/ cluster demonstration, distribution of literature in local language, develop success cases/ model cases, use of ICT media likeVideo conferencing, Kisan Mobile Sandesh, Whats app etc.

\section{ACKNOWLEDGEMENT / FUNDING}

Authors are very grateful to the ICAR, New Delhi for providing financial assistance for conducting Cluster Front Line demonstrations on Chickpea and thankful to host institution for providing facilities. We are also thankful to farmers for providing land and support to conducting experiments.

\section{REFERENCES}

[1] Ali, M. and Kumar, S. 2005. Yet to see a breakthrough. In: Survey of Indian agriculture. The Hindu, Chennai, India, pp. 55-56.

[2] Anonymous.2017. Second advanced estimates of area, production and yield of major kharif/rabicrops of Gujarat State for the year 2017-18, Director of Agriculture, Gujarat State, Gandhinagar,2017.

[3] Choudhary, B. N. (1999). KrishiVigyan Kendra- a guide for KVK manager. Division of Agriculture Extension, ICAR, pp. 73-78.

[4] FAOSTAT, 2017. FAOSTAT Agriculture data. Available at http://faostat.fao.org/>accessed 11 March,2019.

[5] Hiremath, S. M. and Nagaraju, M. V. 2010. Evaluation of on-farm front line demonstrations on the yield of chilli. Karnataka J of Agricultural Sciences,23(2):341-342.

[6] Jeengar K. L., Panwar P., Pareek O.P. 2006. Front line demonstration on maize in Bhilwara District of Rajasthan. Current Agriculture. 30(1/2):115-116.

[7] Kadian, K. S., Sharma, R. and Sharma, A. K. 1997. Evaluation of front line demonstration trials on oilseeds in KangraVally of Himachal Pradesh. Ann. Agric. Res.18:40.

[8] Mitra, B. and Samajdar, T. 2010. Field gap analysis of rapeseed-mustard through front line demonstration. Agricultural Extension Review, 22: 16-17.

[9] Mokidue, I., Mohanty, A. K. and Sanjay, K. 2011. Correlating growth, yield and adoption of uradbean technologies, Indian Journal of Extension Education, 11(2):20-24.

[10] Mukherjee, N. (2003). Participatory, Learning and Action. Concept Publishing Company, New Delhi, pp. 63-65.

[11] Patel, M. M., Jhajharia, A. K., Khadda, B. S. and Patil, L. M. 2013. Front-line Demonstration: An effective communication approach for dissemination of sustainable cotton production technology. Indian Journal of Extension Education and Rural Development, 21:60-62.

[12] Prajapati, P. J., Joshi, N. S., Patel, M.L., Parmar, V.S., Gadhiya, K.K. and Hadiya, N.J. 2019. Impact of frontline demonstrations on yield of chickpea (Cicer arietinum L.) in Amreli district of Gujarat state. J. of Pharmacognosy and Phytochemistry; 8(2): 1431-1433. 
[13] Poonia, T.C. and Pithia, M.S. 2011. Impact of front line demonstrations of chickpea in Gujarat. Legume Research.34(4):304-307.

[14] Raj A.D., Yadav, V. and Rathod, J. H. 2013. Impact of Front Line Demonstrations (FLD) on the Yield of Pulses. International Journal of Scientific and Research Publications. 3(9):1-4.

[15] Samui, S.K., Mitra, S., Roy, D.K., Mandal, A.K. and Saha, D. 2000. Evaluation of front line demonstration on groundnut. Journal of the Indian Society Costal Agricultural Research.18(2):180-183.

[16] Singh, A. K., Manibhushan, Bhatt, B.P., Singh, K.M. and Upadhyaya A. 2013. An Analysis of Oilseeds and Pulses Scenario in Eastern India during 2050-51. Journal of Agril. Sci.5 (1) : 241- 249.

[17] Singh, D.,Patel, A.K., Baghel, S.K., Singh, M.S., Singh, A. and Singh, A.K. 2014. Impact of front line demonstration on the yield and economics of chickpea (Cicer arietinum L.) in Sidhi district of Madhya Pradesh. J. Agric. Res., 1(1): 22-25.

[18] Singh, PK. 2002. Impact of participation in planning on adoption of new technology through FLD. MANAGE Extension Research Review, July-Dec.45-48.

[19] Teggelli, Raju G., Patil,D.H., Naik, Ananda, Zaheer Ahamed,B. and Patil,M.C. 2015. Impact of frontline demonstration on the yield and economics of pigeonpea in Kalaburgi district of Karnataka State. I.J.S.N.,6(2):224-227.

[20] Tomar, R. K. S. 2010. Maximization of productivity for chickpea (Cicer arietinum L.) through improved technologies in farmer's field. Indian Journal of Natural Products and Resources 1(4): 515-517.

[21] Upesh Kumar, G.A. Patel, H.P. Patel, R.P. Chudhari and S.S. Darji. 2019. Impact of front line demonstration programme on the yield of chickpea (Cicer arietinum $L$.) in Patan District of Gujarat,India. Agricultural Research Communication centre Journals, DOI:10.18805/LR4081. 